\title{
GROWTH OF INFANTS ON EXCLUSIVE BREASTFEEDING UPTO 6 MONTHS AND THEN ALONG WITH COMPLEMENTARY FEEDING IN A HOSPITAL BASED SURVEY
}

Gupta B K *

\section{ABSTRACT}

OBJECTIVE: To study growth of infants on exculsive breastfeeding for 6 months and further along with complementary feeding upto 12 months of age.

METHODS: This Cross-sectional, Prospective, Hospital Based, Observational study was conducted in Department of Pediatrics, in collaboration with the Department of Gynaecology and Obstetrics, Universal College of Medical Sciences-Teaching Hospital, Bhairahawa, Lumbini, NEPAL on 292 infants born at the hospital and their growth monitored over a period of 12 months. Evaluation of nutritional trends practiced by the people and its effects on growth of infants was done and compared to the growth of infants according to the NCHS-WHO (CDC-2000) standards.

RESULTS: The average weight at birth and average weight- for- age for both male and female infants were lower than the $50^{\text {th }}$ perentile of National Center for Health Statistic (NCHS) standards. The average length of the infants was found lower than $50^{\text {th }}$ percentile curve of NCHS. The difference of length between boys and girls was insignificant at 6 months $(Z<1.88)$. The average head circumference in our study was below $50^{\text {th }}$ percentile of NCHS standard. The difference between weight, length, mid arm and head circumference of boys and girls was insignificant at 6, 9, 12 months $(\mathrm{Z}<1.88)$.

CONCLUSIONS: Most of the values represent normal growth but the gain in weight and length of infants was far below the $50^{\text {th }}$ percentile of NCHS-WHO standards.

KEY WORDS: Infants, exclusive breastfeeding, complementary feeding, growth assessment.

* Dr. Badri Kumar Gupta, Assistant Professor, Department of Paediatrics, Universal College of Medical Sciences \& Teaching Hospital, Bhairahawa, Nepal

For Correspondence:

Dr. Badri Kumar Gupta

Assistant Professor

Department of Paediatrics

Universal College of Medical Sciences \& Teaching Hospital

Bhairahawa, Nepal

E-mail: drbadrikgupta@gmail.com 


\section{INTRODUCTION}

Adequate nutrition during infancy is crucial for child survival, optimal growth and development throughout life. ${ }^{1}$ The World Health Organization (WHO) recommends exclusive breastfeeding (EBF) for the first six months of life. ${ }^{2}$ After six months, infants should receive nutritionally adequate and safe complementary foods while continuing to be breastfed until the age of two years or beyond. The benefit of EBF for growth, immunity and prevention of illness in young infants is undisputable. ${ }^{3,4}$ It has been postulated that $13 \%$ of the current under five mortality rate could be averted by promoting proper breastfeeding practices, ${ }^{5}$ which is seemingly the single most cost effective intervention to reduce child mortality in resource-constrained settings such as in Nepal. ${ }^{6}$ The importance of EBF for optimal growth and development, irrespective of country of residence, is also reflected in the recent WHO growth standard for children. ${ }^{7}$ Introduction of foods other than breast milk before six months of life is not only undesirable, but could also be harmful. ${ }^{8}$ These foods not only displace nutritious mother's milk, but also serve as a vehicle for infectious pathogens that can lead to severe illness. Despite well-established guidelines for promotion of EBF, the adherence to EBF is quite low in many settings. ${ }^{9 \cdot 11}$ Childhood malnutrition and growth faltering affects more than half of children under five in developing countries, and usually starts during infancy, possibly due to improper breastfeeding and mixed feeding practices. ${ }^{12}$

\section{MATERIAL AND METHOD}

It was a in this prospective longitudinal hospital based study was conducted in the Department of Pediatrics, Universal College of Medical Sciences-Teaching Hospital, Bhairahawa, Lumbini, NEPAL on 292 infants born at the hospital and their growth monitored over a period of 12 months from Sep. 2011 to Aug. 2012.

Those newborn infants delivered in this hospital, all the babies were exclusively breastfed starting immediately after birth. The anthropometric measurements were recorded on the same day. Mothers and attendants were convinced only for breast feeding for the first six months of life and they were daily reinforced for the breastfeeding at the time of discharge from hospital they were advised motivated to come at monthly interval for anthropometric measurements and check up in pediatrics out patient department.

At every visit a thorough physical examination was carried out which included weight, length, head circumference and chest circumference. The method used for recording anthropometric measurements were as per standard technique on a separate proforma for each child after 6 months of age, mother's were advised to give their babies breastfeeding plus complementary feeding. Mothers were interviewed to obtain information regarding weaning practices, age at which weaning started, methods of making traditional weaning foods, factors affecting weaning practices and what weaning food were obtained from family diet.

Ethical clearance from the institutional ethic committee and permission from the parents were obtained in writing.

Statistical analysis appropriate statistical tool was applied to analyse the result.

\section{RESULTS}

Out of 292 infants $152(52.05 \%)$ were male and 140 (47.94\%) were female.

The total cases who came for regular follow up till the end of study were 105 , of these $68(64.76 \%)$ were males and 37 $(35.23 \%)$ were females.

According to Kuppuswamy classification of socio economics status, $15.5 \%, 37.1 \%$ and $48.2 \%$ babies belonged to socioeconomic class II, III and IV respectively.

Out of total 292 cases $215(73.4 \%)$ were Hindus, 66 (22\%) were Muslims and $11(3.8 \%)$ were Christians. $72(22.8 \%)$ cases belonged to urban area and $220(76.3 \%)$ to rural areas.

$121(42 \%)$ mothers knew about early contact, 70(24\%) knew rooming in $20(24 \%)$ knew proper position and attachment for breastfeeding and 31 (11\%) knew milk expression technique. Out of the total 292 mothers 220 were from rural areas and 72 mothers were from urban areas

The age of introduction of complementary food, type and amount of food given, factors affecting weaning were studied. Out of the 172 infants left in the study at this point, $110(64 \%)$ children were given complementary feed at 6-8 months of age, $50(30 \%)$ were given complementary feed at $8-10$ months of age and $12(7 \%)$ children were given complementary feed at 10 months of age

The types of foods used were pulses, rice, roti (wheat), milk (cow, buffalo, goat), vegetables (green leafy vegetables and potato) \& fruits (banana \& apple). The most common weaning food used was pulse in $118(68 \%)$ children, next common being animal milk in $88(51.5 \%)$ children. Rice was used as complementary food in $46(27 \%)$, vegetables and fruits in 23 
$(14 \%)$ and roti of wheat flour in $10(6.1 \%)$, suji was used in $6(3.6 \%)$ and biscuit in $1(0.4 \%)$ child. There was no relation between early or late introduction of complementary food with the type of weaning food, however, cow and buffalo milk was more frequently used in those children who were weaned early as compared to those who are weaned late.

TABLENO. 1 AVERAGE WEIGHT IN KG. AND STANDARD DEVIATION

\begin{tabular}{|c|c|c|c|c|c|c|c|}
\hline $\begin{array}{c}\text { Age in } \\
\text { Month }\end{array}$ & $\begin{array}{c}\text { At } \\
\text { Birth }\end{array}$ & $\begin{array}{c}1 \\
\text { Month }\end{array}$ & $\begin{array}{c}2 \\
\text { Month }\end{array}$ & $\begin{array}{c}3 \\
\text { Month }\end{array}$ & $\begin{array}{c}4 \\
\text { Month }\end{array}$ & $\begin{array}{c}6 \\
\text { Month }\end{array}$ & Month \\
\hline Boys Weight & $3.06 \mathrm{Kg}$. & $3.92 \mathrm{Kg}$. & $4.65 \mathrm{Kg}$. & $5.44 \mathrm{Kg}$. & $6.12 \mathrm{Kg}$. & $6.5 \mathrm{Kg}$. & $7.04 \mathrm{Kg}$. \\
S.D. & 0.366 & 0.557 & 0.690 & 0.759 & 0.752 & 0.656 & 0.655 \\
\hline Girls Weight & $3.01 \mathrm{Kg}$. & $3.74 \mathrm{Kg}$. & $4.5 \mathrm{Kg}$. & $5.21 \mathrm{Kg}$. & $5.88 \mathrm{Kg}$. & $6.41 \mathrm{Kg}$. & $6.8 \mathrm{Kg}$. \\
S.D. & 0.347 & 0.431 & 0.497 & 0.556 & 0.664 & 0.667 & 0.676 \\
\hline
\end{tabular}

Growth : During $1^{\text {st }} 6$ months when infants were exclusively breast fed.

Weight : The average weight was $3.06 \pm 0.36,3.92 \pm 0.557,4.65 \pm 0.690,5.44 \mathrm{Kg} \pm 0.759,6.12 \pm 0.752,6.5 \pm 0.656,7.04 \pm 0.655$, in boys \& $3.01 . \pm 0.347,3.74 \pm 0.431,4.51 \pm 0.497,5.21 \pm 0.556,5.88 \pm 0.664,6.41 \pm 0.667,6.84 \pm 0.676$ in girls at birth, $1,2,3,4,5$ and $6^{\text {th }}$ months respectively (Table 1 ).

As it is apparent from table 4 that $58(46.6 \%)$ boys in $4^{\text {th }}$ month, $38(29.2 \%)$; , boys in $5^{\text {th }}$ month \& $30(24.2 \%)$ boys in $6^{\text {th }}$ month doubled their birth weight and $33(40.8 \%)$ girls in the $4^{\text {th }}$ month, $37(46.2 \%)$ girls in the $5^{\text {th }}$ month and $11(13.1 \%)$ girls in the $6^{\text {th }}$ month also doubled their birth weight.

Length: The average length was $50.5 \mathrm{~cm} \pm 1.94,54.3 \pm 2.05,56.5 . \pm 2.10,60.1 \pm 2.31,62.6 \pm 2.34,64.8 \pm 2.14,66.5 \pm 2.20$ in boys and $48.1 \pm 1.83,53.1 \pm 1.81,56.3 \pm 1.81,58.9 \pm 1.88,61.7 \pm 2.15,63.1 \pm 2.23,64.4 \pm 2.32$, in girls at birth, 12345 and 6 th month of age respectively

TABLE NO. 2 AVERAGE HEAD CIRCUMFERENCE IN CMS. \& STANDARD DEVIATION (BOYS \& GIRLS)

\begin{tabular}{|c|c|c|c|c|c|c|c|}
\hline $\begin{array}{c}\text { Age in } \\
\text { Month }\end{array}$ & $\begin{array}{c}\text { At } \\
\text { Birth }\end{array}$ & $\begin{array}{c}1 \\
\text { Month }\end{array}$ & $\begin{array}{c}2 \\
\text { Month }\end{array}$ & $\begin{array}{c}3 \\
\text { Month }\end{array}$ & $\begin{array}{c}4 \\
\text { Month }\end{array}$ & $\begin{array}{c}5 \\
\text { Month }\end{array}$ & Month \\
\hline Boys & $34.3 \mathrm{Cms}$. & $36.6 \mathrm{Cms}$. & $38.1 \mathrm{Cms}$. & $39.6 \mathrm{Cms}$. & $41.1 \mathrm{Cms}$. & $42.1 \mathrm{Cms}$. & $43.0 \mathrm{Cms}$. \\
S.D. & 1.166 & 1.11 & 1.113 & 1.09 & 1.11 & 1.07 & 1.04 \\
\hline Girls & $33.3 \mathrm{Cms}$. & $35.5 \mathrm{Cms}$. & $36.9 \mathrm{Cms}$. & $38.0 \mathrm{Cms}$. & $39.2 \mathrm{Cms}$. & $40.2 \mathrm{Cms}$. & $41.3 \mathrm{Cms}$. \\
S.D. & 0.811 & 0.924 & 0.95 & 0.95 & 1.02 & 0.984 & 0.94 \\
\hline
\end{tabular}

Head Circumference

The average head circumference was $34.3 \pm 1.166,36.6 \pm 1.11,38.1 \pm 1.113,39.6 \pm 1.09,41.1 \pm 1.11,42.0 \pm 1.07,43.0 \pm$ $1.04 \mathrm{cms}$ in boys and $33.3 \pm 0.811,35.5 \pm 0.924,36.9 \pm 0.95,38.0 \pm 0.95,39.2+1.02,40.2 \pm 0.984,41.3 \pm 0.94, \mathrm{~cm}$ in girls at birth 1, 2, 3, 4, 5 \& 6 months of age respectively

Chest Circumference

The average chest circumference was $33 \pm 1.35,34.6 \pm 1.26,36.1 \pm 1.24,37.2 \pm 1.28,38.4 \pm 1.05,39.2 \pm 0.96,40.3 \pm 1.16 \mathrm{~cm}$ in boys and $30.4 \pm 1.27,32.6, \pm 1.28,34.5 \pm 1.58,35.70 \pm 1.46,36.9 \pm 1.32,38 \pm 1.23,38.8 \pm 1.27 \mathrm{~cm}$. in girls at birth $1,2,3,4,5$ and $6^{\text {th }}$ months of age respectively

\section{AVERAGE CHEST CIRCUMFERENCE IN CMS. \& STANDARD}

Mid arm Circumference

The average mid arm circumference was $10.0 \pm 0.8,10.7 \pm 0.9,11.2 \pm 0.7,12.0 \pm 0.7,12.5 \pm 0.72,12.9 \pm 0.63$ and $13.4 \pm 0.78 \mathrm{~cm}$ in 
boys and $9.6 \pm 0.8,10.6 \pm 0.8,11.3 \pm 0.7,11.9 \pm 0.79,12.5 \pm 0.924,12.9 \pm 0.9,13.3 \pm 0.8 \mathrm{~cm}$ in girls at birth, $1,2,3,4,5$ and 6 months of age respectively

TABLE NO. 3 AVERAGE WEIGHT IN KG. AND STANDARD DEVIATION.

\begin{tabular}{|c|c|c|c|c|c|c|}
\hline Age in Month & $\begin{array}{c}7 \\
\text { Month }\end{array}$ & $\begin{array}{c}8 \\
\text { Month }\end{array}$ & $\begin{array}{c}9 \\
\text { Month }\end{array}$ & $\begin{array}{c}10 \\
\text { Month }\end{array}$ & $\begin{array}{c}11 \\
\text { Month }\end{array}$ & $\begin{array}{c}12 \\
\text { Month }\end{array}$ \\
\hline $\begin{array}{l}\text { Complementary Boys Weight Feed at } \\
\text { S.D. } \\
\text { 6-8 Month }\end{array}$ & $\begin{array}{c}7.45 \mathrm{Kg} . \\
0.609\end{array}$ & $\begin{array}{c}7.96 \mathrm{Kg} . \\
0.671\end{array}$ & $\begin{array}{c}8.29 \mathrm{Kg} . \\
0.797\end{array}$ & $\begin{array}{c}8.59 \mathrm{Kg} . \\
0.910\end{array}$ & $\begin{array}{c}8.85 \mathrm{Kg} . \\
0.889\end{array}$ & $\begin{aligned} 9.13 \mathrm{Kg} \\
0.991\end{aligned}$ \\
\hline $\begin{array}{c}\text { Girls Weight } \\
\text { S.D. } \\
\end{array}$ & $\begin{array}{c}7.27 \mathrm{Kg} . \\
0.688\end{array}$ & $\begin{array}{l}7.6 \mathrm{Kg} . \\
0.755\end{array}$ & $\begin{array}{c}7.85 \mathrm{Kg} . \\
0.797\end{array}$ & $\begin{array}{c}8.08 \mathrm{Kg} . \\
0.832\end{array}$ & $\begin{array}{c}8.35 \mathrm{Kg} . \\
0.851\end{array}$ & $\begin{array}{c}8.6 \mathrm{Kg} . \\
0.929\end{array}$ \\
\hline $\begin{array}{l}\text { Complementary Boys Weight Feed at } \\
\text { S.D. } \\
\text { 8-10 Month }\end{array}$ & $\begin{array}{l}7.31 \mathrm{Kg} . \\
0.572\end{array}$ & $\begin{array}{l}7.54 \mathrm{Kg} . \\
0.701\end{array}$ & $\begin{array}{l}7.82 \mathrm{Kg} . \\
0.652\end{array}$ & $\begin{array}{l}8.14 \mathrm{Kg} . \\
0.608\end{array}$ & $\begin{array}{c}8.38 \mathrm{Kg} . \\
0.639\end{array}$ & $\begin{array}{c}8.63 \mathrm{Kg} . \\
0.690\end{array}$ \\
\hline $\begin{array}{r}\text { Girls Weight } \\
\text { S.D. }\end{array}$ & $\begin{array}{c}7.12 \mathrm{Kg} . \\
0.607\end{array}$ & $\begin{array}{c}7.46 \mathrm{Kg} . \\
0.799\end{array}$ & $\begin{array}{c}7.64 \mathrm{Kg} . \\
0.758\end{array}$ & $\begin{array}{c}7.82 \mathrm{Kg} . \\
0.749\end{array}$ & $\begin{array}{c}8.04 \mathrm{Kg} . \\
0.699\end{array}$ & $\begin{array}{c}8.32 \mathrm{Kg} . \\
0.576\end{array}$ \\
\hline $\begin{array}{l}\text { Complementary Boys Weight Feed at } \\
\text { S.D. } \\
10 \text { Month }\end{array}$ & $\begin{array}{l}7.24 \mathrm{Kg} . \\
0.370\end{array}$ & $\begin{array}{l}7.52 \mathrm{Kg} . \\
0.379\end{array}$ & $\begin{array}{l}7.83 \mathrm{Kg} . \\
0.399\end{array}$ & $\begin{array}{c}8.05 \mathrm{Kg} . \\
0.360\end{array}$ & $\begin{array}{c}8.25 \mathrm{Kg} . \\
0\end{array}$ & $\begin{array}{l}8.55 \mathrm{Kg} . \\
0\end{array}$ \\
\hline $\begin{array}{r}\text { Girls Weight } \\
\text { S.D. }\end{array}$ & $\begin{array}{c}7.10 \mathrm{Kg} . \\
0.774\end{array}$ & $\begin{array}{c}7.424 \mathrm{Kg} . \\
0.662\end{array}$ & $\begin{array}{c}7.61 \mathrm{Kg} . \\
0.824\end{array}$ & $\begin{array}{c}7.81 \mathrm{Kg} . \\
0.361\end{array}$ & $\begin{array}{c}8.02 \mathrm{Kg} . \\
0.859\end{array}$ & $\begin{array}{c}8.30 \mathrm{Kg} . \\
0.600\end{array}$ \\
\hline
\end{tabular}

\section{AVERAGE MID ARM CIRCUMFERENCE IN CMS. \& STANDARD}

Growth of Children in Relation to Age of Introduction of Complementary Feed:-

Weight : The average weight of children who were given complementary feed at 6-8 month of age was 7.45 $\pm 0.609,7.96 \pm 0.671$, $8.29 \pm 0.797,8.59 \pm 0,910,8.85 \pm 0.889,9.13 \pm 0.911 \mathrm{~kg}$ in boys and $7.27 \pm 0.688,7.6 \pm 0.755,7.85 \pm .0,797,8.08+0.832,8.35 \pm$ $0.851,8.6 \pm 0.929 \mathrm{~kg}$. in girls at. 7, 8, 9, 10,11 and 12 months of age respectively (Table 9).(Table 3 )

In infants who were given complementary feed at 8-10 months of age, the average weight was 7.31 $\pm 0.572,7.54 \pm 0.701$, $7.82 \pm 0.652,8.14 \pm 0.608,8.38 \pm 0.639,8.63 \pm 0.690 \mathrm{~kg}$ in boys and $7.12 \pm 0.607,7.46 \pm 0.779,7.64 \pm 0.764,7.82 \pm 0.749,8.04 \pm 0.699$, $8.30 \pm 0.576 \mathrm{~kg}$ in girls at $7,8,9,10,11$ and 12 months of age respectively.

TABLE NO. 4 AVERAGE LENGTH IN CMS. AND STANDARD DEVIATION ACCORDING TO AGE OF INTRODUCTION OF COMPLEMENTARY FEED

\begin{tabular}{|c|c|c|c|c|c|c|}
\hline Age in Month & $\begin{array}{c}7 \\
\text { Month }\end{array}$ & $\begin{array}{c}8 \\
\text { Month }\end{array}$ & $\begin{array}{c}9 \\
\text { Month }\end{array}$ & $\begin{array}{c}10 \\
\text { Month }\end{array}$ & $\begin{array}{c}11 \\
\text { Month }\end{array}$ & $\begin{array}{c}12 \\
\text { Month }\end{array}$ \\
\hline $\begin{array}{l}\text { Complementary Boys Length Feed at } \\
\text { S.D. } \\
6-8 \text { Month }\end{array}$ & $\begin{array}{l}68.2 \mathrm{Cms} . \\
2.03\end{array}$ & $\begin{array}{l}69.7 \mathrm{Cms} . \\
2.224\end{array}$ & $\begin{array}{l}70.8 \mathrm{Cms} \text {. } \\
2.25\end{array}$ & $\begin{array}{l}71.8 \mathrm{Cms} . \\
2.08\end{array}$ & $\begin{array}{l}72.8 \mathrm{Cms} \text {. } \\
2.03\end{array}$ & $\begin{array}{l}73.8 \mathrm{Cms} . \\
2.12\end{array}$ \\
\hline $\begin{array}{r}\text { Girls Length } \\
\text { S.D. } \\
\end{array}$ & $\begin{array}{l}65.8 \mathrm{Cms} \\
2.00\end{array}$ & $\begin{array}{l}66.9 \mathrm{Cms} . \\
2.11\end{array}$ & $\begin{array}{l}68.2 \mathrm{Cms} . \\
2.10\end{array}$ & $\begin{array}{l}69.3 \mathrm{Cms} . \\
1.98\end{array}$ & $\begin{array}{l}70.5 \mathrm{Cms} \\
2.23\end{array}$ & $\begin{array}{l}71.6 \mathrm{Cms} . \\
2.26\end{array}$ \\
\hline $\begin{array}{l}\text { Complementary Boys Length Feed at } \\
\text { S.D. } \\
\text { 8-10 Month }\end{array}$ & $\begin{array}{l}68 \mathrm{Cms} . \\
1.81\end{array}$ & $\begin{array}{l}69.2 \mathrm{Cms} \\
2.15\end{array}$ & $\begin{array}{l}70.3 \mathrm{Cms} . \\
2.24\end{array}$ & $\begin{array}{l}71.3 \mathrm{Cms} \\
2.34\end{array}$ & $\begin{array}{l}72.1 \mathrm{Cms} . \\
2.36\end{array}$ & $\begin{array}{l}73.3 \mathrm{Cms} . \\
2.38\end{array}$ \\
\hline $\begin{array}{r}\text { Girls Length } \\
\text { S.D. }\end{array}$ & $\begin{array}{l}65.4 \mathrm{Cms} \\
2.34\end{array}$ & $\begin{array}{l}66.8 \mathrm{Cms} . \\
2.51\end{array}$ & $\begin{array}{l}68.0 \mathrm{Cms} . \\
2.21\end{array}$ & $\begin{array}{l}39.2 \mathrm{Cms} \\
2.26\end{array}$ & $\begin{array}{l}70.3 \mathrm{Cms} . \\
2.32\end{array}$ & $\begin{array}{l}71.3 \mathrm{Cms} . \\
2.32\end{array}$ \\
\hline $\begin{array}{l}\text { Complementary Boys Length Feed at } \\
\text { S.D. }\end{array}$ & $\begin{array}{l}68.0 \mathrm{Cms} . \\
0.449\end{array}$ & $\begin{array}{l}69.2 \mathrm{Cms} . \\
0.550\end{array}$ & $\begin{array}{l}70.1 \mathrm{Cms} . \\
0.549\end{array}$ & $\begin{array}{l}71.1 \mathrm{Cms} \\
0.599\end{array}$ & $\begin{array}{c}72.1 \mathrm{Cms} . \\
-\end{array}$ & $\begin{array}{c}73.5 \mathrm{Cms} . \\
-\end{array}$ \\
\hline $\begin{array}{r}\text { Girls Length } \\
\text { S.D. }\end{array}$ & $\begin{array}{l}65.3 \mathrm{Cms} . \\
2.03\end{array}$ & $\begin{array}{l}66.5 \mathrm{Cms} . \\
2.14\end{array}$ & $\begin{array}{l}68.0 \mathrm{Cms} . \\
2.33\end{array}$ & $\begin{array}{l}69.0 \mathrm{Cms} . \\
2.04\end{array}$ & $\begin{array}{l}70.2 \mathrm{Cms} \\
1.84\end{array}$ & $\begin{array}{l}71.3 \mathrm{Cms} . \\
1.34\end{array}$ \\
\hline
\end{tabular}


Length : The average length in children who were weaned at 6-8 months of age was $68.2 \pm 2.03,69.7 \pm 2.224,70.8 \pm 2.25,71.8 \pm$ $2.08,72.83 \pm 2.03 \& 73.8 \pm 2.12 \mathrm{cms}$. in boys and $65.8 \pm 2.00,66.9 \pm 2.11,68.2 \pm 2.10,69.3 \pm 1.98,70.5 \pm 2.23 \& 71.6 \pm 2.26 \mathrm{cms} .1 \mathrm{n}$ girls at 7, 8, 9, 10, 11 and 12 months of age respectively

Average length of children who were weaned at 8-10 months of age was $68 \pm 1.81,69.2 \pm 2.15,70.32 .24,71.3 \pm 2.34,72.1 \pm$ $2.36,73.3 \pm 2.38$ in boys and $65.4 \pm 2.34,66.8 \pm 2.51,68.0 \pm 2.21,69.2 \pm 2.26,70.3+2.32,71.3+2.32$ in girls at $7,8,9,10$, 11 and 12 months of age (Table 10).

When weaning was started at 10 months of age, the average length was $68.0 \pm 0.449,69.2 \pm 0.550,70.1 \pm 0.549,71.1 \pm$ $0.599,72.0 \pm 0,73.5 \pm 0$ in boys and $65.3 \pm 2.03,66.5 \pm 2.14,98.0 \pm 2.33,69.0 \pm 2.04,70.2 \pm 0.84,71.3 \pm 1.34 \mathrm{~cm}$ in girls at $7,8,9,10,11$ and 12 months of age

TABLE NO.5 AVERAGE HEAD CIRCUMFERENCE IN CMS. AND STANDARD DEVIATION

\begin{tabular}{|c|c|c|c|c|c|c|c|}
\hline \multicolumn{2}{|c|}{ Age in Month } & $\begin{array}{c}7 \\
\text { Month }\end{array}$ & $\begin{array}{c}8 \\
\text { Month }\end{array}$ & $\begin{array}{c}9 \\
\text { Month }\end{array}$ & $\begin{array}{c}10 \\
\text { Month }\end{array}$ & $\begin{array}{c}11 \\
\text { Month }\end{array}$ & $\begin{array}{c}12 \\
\text { Month }\end{array}$ \\
\hline \multirow{3}{*}{\multicolumn{2}{|c|}{\begin{tabular}{lll}
\multicolumn{2}{l}{ Complementary } & H.C. \\
Feed at & Boys & S.D. \\
6-8 Month & & H.C.
\end{tabular}}} & 43.7 & 44.2 & 44.7 & 45.2 & 45.7 & 46.1 \\
\hline & & 1.04 & 0.951 & 1.01 & 1.00 & 0.972 & 0.829 \\
\hline & & 42.1 & 42.6 & 43 & 43.5 & 44 & 44.4 \\
\hline Girls & S.D. & 0.892 & 0.795 & 0.718 & 0.836 & 0.828 & 0.91 \\
\hline \multirow{3}{*}{\multicolumn{2}{|c|}{\begin{tabular}{lll}
\multicolumn{2}{l}{ Complementary } & H.C. \\
Feed at Boys & S.D. \\
8-10 Month & H.C.
\end{tabular}}} & 43.6 & 44.1 & 44.5 & 45.1 & 45.6 & 46 \\
\hline & & 0.94 & 1.03 & 1.038 & 1.02 & 0.889 & 0.86 \\
\hline & & 42 & 42.5 & 43.1 & 43.6 & 44 & 44.4 \\
\hline Girls & S.D. & 0.98 & 0.92 & 0.95 & 0.92 & 1.02 & 1.11 \\
\hline \multirow{3}{*}{\multicolumn{2}{|c|}{$\begin{array}{lll}\text { Complementary } & \text { H.C. } \\
\text { Feed at } \quad \text { Boys } & \text { S.D. } \\
10 \text { Month } & & \text { H.C. }\end{array}$}} & 43.5 & 44.2 & 44.6 & 45.1 & 45.7 & 46.1 \\
\hline & & 0.400 & 0.449 & 0.450 & 0.300 & 0 & 0 \\
\hline & & 42 & 42.4 & 43 & 43.5 & 44 & 44.3 \\
\hline Girls & S.D. & 0.664 & 0.856 & 0.814 & 0.866 & 0.998 & 0.713 \\
\hline
\end{tabular}

Head Circumference: The relation of head circumference to the age of introduction of complementary feeding was not found of much relevance.

The gain in head circumference was slightly higher in groups of children who were given complements at 6-8 months of age. However it was not found to be statistically significant

\section{DISCUSSION}

Weight: Average weight at birth and the average weight gain per month and average age wise weights for both male and female infants in our study were lesser than the average weight gain per month of American children. Our values were lower than the $50^{\text {th }}$ percentile of National center for Health Statistics (NCHS). ${ }^{[13]}$ The weight curve is near to $25^{\text {th }}$ percentile curve of NCHS figures up to the age of 6 months.

On comparing the average weight with NCHS standard, it was observed that the average weight in our study for male infants was $3.0,3.92,4.65,5.44,6.12,6.5$ and $7.04 \mathrm{Kg}$ at birth, $1,2,3,4,5$, and 6 months of age.

The average weight for girls in our study was 3.01, 3.74, 4.51, 5.21, 5.88, 6.41 and 6.84. Our values are lower than 25th percentile of NCHS.

When the weight has been plotted on the growth chart, most of the values represent normal growth but there is a downward trend in percentile chart in comparison to NCHS values. Hence it appears that growth of the babies fed exclusively on breast milk is 
different that artificially fed babies belonging to high socioeconomic status (NCHS).

Length: The average gain in length in first, 2nd and 4th month are lower in male infants and in 3rd month in female infants. The values are comparable at 3, 4 and 5th month of age in male and 2, 3, 4 and 5 months in female infants with 50th percentile values of NCHS.

The average length in our study was $50.5 \mathrm{~cm}, 54.3,56.5,60.1$, $62.6,64.8$ and $66 \mathrm{~cm}$ in male infants and $48.8,53.2,56.3,58.9$, $61.7,63.1$, and $64.4 \mathrm{~cm}$ in female infants at birth $1,2,3,4,5$ and 6 months of age respectively.

Head Circumference: The average gain in head circumference in males in our study is comparable to the 50 th percentile value of NCHS for 1, 3, 4, 5, 6 months but it is lower in 2nd month in male infants.

The average gain in head circumference in case of female infants is comparable in 1, 2, 4, 5 and 6 months except in 3rd month in which it is lower than the $50^{\text {th }}$ percentile values of NCHS.

The average head circumference values in our study is 34.3 , $36.6,36,39.6,41.1$ and $43 \mathrm{~cm}$. in male infants and 33.3, 35.5, $36.9,38.0,39.9,40.2 \& 41.3 \mathrm{~cm}$. in female infants at birth, 1,2 , $3,4,5$ and $6^{\text {th }}$ months of age.

Statistically if one compares with the 50th percentiles of NCHS chart, the difference of average length is found to be significant for 2, 3, \& 4 months $(Z>1.88)$ and is insignificant $(\mathrm{Z}<1.88)$ for 1 and 6 months for male infants. It is insignificant $(Z>1.88)$ in $1,2,3,4 \& 5$ months and is significant in 6 month for female infants. This means that in early infancy the average gain in length is better in both male and female infants, hence it may be true to say that the values given for length in NCHS percentiles chart are similar to the linear growth values of our exclusively breastfed babies.

There is no available standard data of NCHS for chest circumference and mid arm circumference.

\section{GROWTH IN RELATION TO THE AGE OF WEANING WEIGHT AND LENGTH}

In the present study infants who were weaned early (6-8 month) have shown the better gain in weight and length in comparison to children weaned later. However infants weaned up to the age of 10 months also had similar growth as those of weaned early. The study by Khan M.U from rural Bangladesh is similar to our study who also observed gain in weight and length in children weaned early, mid or late and found that weight, ${ }^{14}$ and length gain was almost similar in all the groups up to the age of 24 months irrespective of the time of weaning. Khan has explained this by high occurrence of diarrheal disease in all the weaned group. The study is also comparable to study at Cambridge by Whitehead and Paulas they found that breastfed babies exhibited a demonstrably faster growth velocity up to 3 months than NCHS. ${ }^{15}$ After four months or so this upward trend was reversed, growth velocity decelerated more quickly than that of NCHS.

The relation of weaning age and head circumference was not found relevant. The gain in head circumference was slightly higher for children who were weaned at 6-8 months of age.

There was no relation with the age of weaning and mid-arm circumference. The mid arm circumference was found to be almost equal in all children either weaned early or late.

\section{CONCLUSION}

The overall growth of children in present study irrespective of age of weaning was found lower to the NCHS standard. The average weight of both boys and girls was far below the NCHS 50 percentile. This could be explained by the reason that the NCHS WHO reference data for infants is representative of the United States population demographically and in terms of breast feeding prevalence.

In general breastfed infants tend to gain weight more rapidly in the first 2 to 3 months. From 6 to 12 months breast fed infants tend to weigh less than formula fed infants.

In our study the difference of length between boys and girls was insignificant at 6 months $(Z<1.88)$.

The average gain in length in our study was comparatively better than gain in weight throughout the period of study. The average head circumference in our study was below 50th percentile of NCHS standard. The difference between head circumference of boys and girls was insignificant at $6,9,12$ months $(Z<1.88)$

The average mid-arm circumference values are not available in NCHS standard. There was not much difference between the mid arm circumference of boys and girls $(Z<1.88)$ throughout the period of study.

Children weaned at 6-8 months of age had better growth during this period than those weaned late, but at 1 year of age all infants have similar growth irrespective of weaning age.

CONFLICT OF INTEREST : None

ROLE OF FUNDING SOURCE : None 


\section{REFERENCES:}

1. UNICEF: Strategy for improved nutrition of children and women in developing countries. New York; 1990.

2. WHO: The optimal duration of exclusive breast feeding: reports of an expertconsultation. Geneva, WHO; 2001.

3. Oddy WH, Sly PD, de Klerk NH, Landau LI, Kendall GE, Holt PG, Stanley FJ: Breast feeding and respiratory morbidity in infancy: a birth cohort study. Arch Dis Child 2003, 88(3):224-228.

4. Kalanda BF, Verhoeff FH, Brabin BJ: Breast and complementary feeding practices in relation to morbidity and growth in Malawian infants. Eur J Clin Nutr 2006, 60(3):401-407.

5. Jones G, Steketee RW, Black RE, Bhutta ZA, Morris SS: How many child deaths can we prevent this year? Lancet 2003, 362(9377):65-71.

6. Mullany LC, Katz J, Li YM, Khatry SK, LeClerq SC, Darmstadt GL Tielsch JM: Breast-feeding patterns, time to initiation, and mortality risk among newborns in southern Nepal. J Nutr 2008, 138(3):599603.

7. de Onis $M$, Garza C, Onyango AW, Rolland-Cachera MF: WHO growth standards for infants and young children. Arch Pediatr 2009, 16(1):47-53

8. Haider R, Ashworth A, Kabir I, Huttly SR: Effect of community-based peer counsellors on exclusive breastfeeding practices in Dhaka, Bangladesh: a randomised controlled trial. Lancet 2000, 356(9242):1643-1647.
9. Engebretsen IM, Wamani H, Karamagi C, Semiyaga N, Tumwine J, Tylleskar T: Low adherence to exclusive breastfeeding in Eastern Uganda: a community-based cross-sectional study comparing dietary recall since birth with 24-hour recall. BMC Pediatr 2007, 7:10.

10. Vaahtera M, Kulmala T, Hietanen A, Ndekha M, Cullinan T, Salin ML, Ashorn P:Breastfeeding and complementary feeding practices in rural Malawi. Acta Paediatr 2001, 90(3):328-332.

11. Mihrshahi S, Ichikawa N, Shuaib M, Oddy W, Ampon R, Dibley MJ, Kabir AK, Peat JK:Prevalence of exclusive breastfeeding in Bangladesh and its association with diarrhoea and acute respiratory infection: results of the multiple indicator cluster survey 2003. J Health Popul Nutr 2007, 25(2):195-204.

12. He YN, Zhai F: Complementary feeding practice in Chinese rural children. Wei Sheng Yan Jiu 2001, 30(5):305-307.

13. National Center for Health Statistics : 2000 CDC growth charts, United States. http://www.cdc.gov/growthcharts.

14. Khan $\mathrm{Mu}$, Breast feeding growth and diarrhoea in rural Bangladesh Children Hum Nutr Clinical Nuts, 1983, 38C No. 2 : 113-119.

15. Whitehead RG, Paul AP, Growth chart and the assessment of feeding practices in the western world and in developing countries. Human development 1984; 9: 187-207.

\section{Universal College of Medical Sciences and Teaching Hospital is having following post graduation programmes:-}

1. General surgery

2. Paediatrics

3. Orthopaedics \& Trauma

4. Radio-diagnosis

5. Anaesthesiology

6. Psychiatry

7. Pathology

8. Clinical Anatomy
9. Internal Medicine

10. Obstetrics \& Gynaecology

11. ENT

12. Dermatology

13. Ophthalmology

14. Microbiology

15. MDGP (General Practice)

16. MD Clinical Pharmacology 